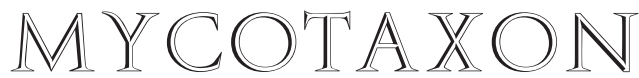

Volume 129(2), pp. 387-395

\title{
First report of the pantropical species Diploschistes rampoddensis from Europe
}

\author{
SAMANTHA FERnÁNDEZ-Brime ${ }^{1,2^{*}}$, XAVIER LlimonA ${ }^{1}$, \\ NÉstor HLAduN ${ }^{1}$, \& Ester Gaya ${ }^{3}$
}

${ }^{1}$ Department of Plant Biology, Facultat de Biologia, Universitat de Barcelona, Barcelona, 08028, Spain

${ }^{2}$ Department of Botany, Swedish Museum of Natural History, Stockholm, SE-104 05, Sweden

${ }^{3}$ Mycology section, Jodrell Laboratory, Royal Botanic Gardens,

Kew, Richmond, Surrey, TW9 3DS, U.K.

*Correspondence to: sfernandezbrime@ub.edu

\begin{abstract}
Aвstract - The lichen species Diploschistes rampoddensis, previously known only from a few localities in tropical and subtropical Asia and Oceania, is reported here for the first time in Europe. A detailed description, including macro- and microscopic characters, and comparisons with closely related taxa are also provided. Molecular analyses based on the nrITS were used to confirm this new record for the European lichen biota.
\end{abstract}

Key words - Ascomycota, BAli-phy, disjunct distribution, lichenized-fungi, Ostropales

\section{Introduction}

The lichen genus Diploschistes Norman (Graphidaceae, Ostropales, Ascomycota) currently includes 45 species (Kirk et al. 2008, Pérez-Vargas et al. 2012, Fernández-Brime et al. 2013), distributed mainly in temperate and arid regions of both hemispheres, with only a few species restricted to the tropics (Lumbsch 1989). One of the few species occurring in tropical areas is D. rampoddensis, a taxon that was first described by Nylander (1900, as Urceolaria rampoddensis) from the locality of Rampodde (Sri Lanka). According to the literature (Nylander 1900, Lumbsch 1993, Pant \& Upreti 1993, Martín et al. 2003) and unpublished herbarium specimens, this species appears to be quite rare and has previously been recorded only from a few localities in tropical and subtropical Asia and Oceania.

As part of an ongoing project to assess the lichen diversity of several protected areas of Catalonia (NE Spain), we intensively surveyed the cliffs of Sant Llorenç 
de la Muga, a protected area included in the Plan of Sites of Natural Interest (PEIN). Among several Diploschistes collections, three samples were initially identified as D. rampoddensis, based on their morphological, anatomical, and chemical features. As these specimens were, however, rather scant or inconspicuous, we checked the identification using the nuclear ribosomal internal transcribed spacer (nrITS), recently selected as the universal DNA barcode marker for fungi (Schoch et al. 2012). Our molecular analyses further confirmed that these specimens represent $D$. rampoddensis, which extends its distributional range to Europe.

\section{Materials \& methods}

\section{Morphological analysis}

The morphological study was carried out on fresh specimens collected from the cliffs of Sant Llorenç de la Muga and on herbarium material of Diploschistes rampoddensis lodged and loaned from UPS, as well as on other taxa of Diploschistes used for comparison. Morphological characters were examined with an Olympus VMZ dissecting microscope $(40 \times)$. Anatomical characters were studied on hand-cut sections mounted in water $(40 \times)$ or oil immersion (100x) using an Olympus CH-2 light microscope. Vouchers of new specimens were conserved in CeDocBiV, Universitat de Barcelona, Spain (BCN), Institute of Botany, Academy of Sciences, Czech Republic (PRA), and the first author's private herbarium (Hb. Fdez.-Brime, SFB).

Selected specimens were photographed using a Pixera Pro150 ES camera mounted on an Olympus SZ60 stereomicroscope. For each selected specimen, multiple images in different focal planes were taken and subsequently assembled into a final unique picture using the software Helicon Focus 5.2.

Spot tests were performed using standard lichenological chemical reagents $(\mathrm{K}, \mathrm{C})$ along with thin-layer chromatography (TLC) following the protocols of Orange et al. (2001).

\section{Molecular analysis}

Genomic DNA was obtained from small pieces of thallus and apothecia sampled from fresh specimens using a phenol-chloroform-isoamyl alcohol extraction protocol based on Lee et al. (1988). Approximately $560 \mathrm{bp}$ including the complete nrITS region was amplified using the primers ITS1F (Gardes \& Bruns 1993) and ITS4 (White et al. 1990). PCR mixtures were prepared as in Gueidan et al. (2007) and conditions for thermocycling followed Fernández-Brime et al. (2013). The nrITS region was sequenced as detailed in Martín \& Winka (2000), using the same amplification primers.

We aligned the nrITS of the three specimens tentatively identified as Diploschistes rampoddensis with the only nrITS sequence of $D$. rampoddensis available from GenBank, together with other sequences of closely related representatives of Diploschistes subg. Diploschistes (Fernández-Brime et al. 2013). Diploschistes actinostomus (Ach.) Zahlbr. and D. candidissimus (Kremp.) Zahlbr., from Diploschistes subg. Limborina Fdez.-Brime et al. (Fernández-Brime et al. 2013) were selected as outgroups to root the phylogeny. A total of 17 sequences were used for the phylogenetic analyses (TABLE 1). All newly 
TABLE 1. Specimens and sequences of Diploschistes used in the present phylogenetic analysis.

\begin{tabular}{|c|c|c|c|}
\hline SPECIES & VOUCHER & ORIGIN & GENBANK $^{*}$ \\
\hline D. actinostomus & BCC-Lich 13394 & Spain, Catalonia & AF229194 \\
\hline D. candidissimus & ESS 20699 & Australia, South Australia & AJ458281 \\
\hline \multirow[t]{3}{*}{ D. cinereocaesius } & ESS 9364 & Venezuela, Mérida & AJ458282 \\
\hline & DUKE 0047509 & Costa Rica, San José & HQ650715 \\
\hline & Hb. Palice, Palice 4471 & Ecuador & KJ542542 \\
\hline \multirow[t]{4}{*}{ D. rampoddensis } & Hb. Lumbsch, Aptroot 39679 & Papua New Guinea & AJ458286 \\
\hline & BCC-Lich 18009 & Spain, Catalonia & KC166992 \\
\hline & BCC-Lich 18011 & Spain, Catalonia & KC166993 \\
\hline & BCC-Lich 18008 & Spain, Catalonia & KJ542543 \\
\hline \multirow[t]{4}{*}{ D. scruposus } & BCN-Lich 19326 & Spain, Catalonia & $\mathrm{KC} 167067$ \\
\hline & Hb. Fdez.-Brime, SFB 59 & Spain, Catalonia & KJ542545 \\
\hline & Hb. Fdez.-Brime, SFB 103 & Spain, Catalonia & KJ542546 \\
\hline & ESS 21508 & Germany, Rheinland-Pfalz & AJ458287 \\
\hline \multirow[t]{4}{*}{ D. scruposus "interpediens" } & BCN-Lich 19319 & Spain, Catalonia & KC166995 \\
\hline & BCN-Lich 19355 & Spain, Catalonia & KC166999 \\
\hline & BCN-Lich 19322 & $\begin{array}{l}\text { France, Languedoc- } \\
\text { Roussillon }\end{array}$ & KC167003 \\
\hline & Hb. Fdez.-Brime, SFB 104 & Spain, Catalonia & KJ542544 \\
\hline
\end{tabular}

* Newly obtained sequences shown in bold.

generated DNA sequences are now deposited in GenBank (KJ542542-KJ542546) and the alignment is available in TreeBASE (http://www.treebase.org; ID number 15496).

Sequences were manually aligned with Mesquite 2.75 (Maddison \& Maddison 2011). Terminal primers and partial nuSSU and nuLSU were excluded from the alignment. Phylogenetic relationships were inferred using weighted maximum parsimony (wMP) and Bayesian methods (B). The wMP analyses were carried out in PAUP* v.4.0b10 (Swofford 2002), with gaps treated as a fifth character state in unambiguously aligned regions. These regions were subjected to symmetric step matrices (i.e., ITS1, 5.8S, and ITS2 being treated separately), using STMatrix v.3.0 (F. Lutzoni \& S. Zoller, Dept. of Biology, Duke University), as outlined in Gaya et al. (2003). Ambiguously aligned regions were removed from the wMP searches and recoded and incorporated into the analyses using INAASE v.2.3b (Lutzoni et al. 2000), as in Gaya et al. (2008). All wMP analyses were performed using heuristic searches with 1000 random addition sequences (RAS), the tree bisection-reconstruction (TBR) algorithm, MULTREES in effect, and collapsing branches with maximum branch length equal to zero. Branch support (BS) was assessed with 1000 bootstrap replicates (Felsenstein 1985) with full heuristic searches, and 2 RAS per bootstrap replicate. In all BS analyses, the same parameters as in the original MP search were used, and constant sites were excluded from all analyses. The Bayesian analyses (B) were done using BAli-Phy 2.1.1 (Suchard \& Redelings 2006), a software that simultaneously accounts for alignment uncertainty and phylogeny, allowing the inclusion of the whole alignment. In this case, the nrITS dataset was divided into three partitions (ITS1, 5.8S, and ITS2) as suggested in Gaya et 
al. (2011). The analyses were run under the following settings: ITS1 and ITS2 sharing the same model of evolution $(\mathrm{HKY}+\mathrm{G})$, indel model (RS07; Redelings \& Suchard 2007) and branch length estimation, while the EQU model and separate branch length estimation were applied to the partition $5.8 \mathrm{~S}$, which was fixed because the alignment was unambiguous. We ran 6 independent Markov chains of 50,000 iterations each, sampling the Markov chains every 10 iterations. After discarding the first 1250 samples of each run $(25 \%)$, we computed the majority rule consensus with the remaining trees $(22,500)$.

\section{Results \& discussion}

\section{Molecular phylogenetics}

The final nrITS alignment included 17 taxa and comprised 594 characters. We excluded from the wMP analyses 557 characters, of which 407 were constant sites and 150 corresponded to 19 ambiguously aligned regions. The characters from the ambiguously aligned regions were included as 19 INAASE recoded characters. From the 56 variable characters analyzed by wMP, 40 were parsimony-informative. We included the whole alignment for the B analyses.

The wMP search yielded six most parsimonious trees of 159.27 steps, which were found in one island hit 991 times out of 1000 RAS. The strict consensus tree (FIG. 1) shows 13 resolved internodes, of which nine were significantly supported (BS $\geq 70 \%$ ). The $50 \%$ majority rule consensus tree from the B analyses showed slightly less resolution, with nine resolved internodes, but, as with wMP, nine of these were significantly supported ( $\mathrm{PP} \geq 0.95)$.

The three European specimens putatively representing Diploschistes rampoddensis clustered with the only sequence of $D$. rampoddensis from GenBank and formed a well-supported clade (BS $=100 \%$; PP $=1$ ). This clade was sister to D. cinereocaesius (Sw.) Vain., which provided support for this sister relationship for the first time. In contrast, specimens of other taxa [e.g., Diploschistes scruposus (Schreb.) Norman, D. scruposus "morphotypus interpediens")], even if morphologically similar and collected from the same locality of Sant Llorenç de la Muga (specimens marked with an asterisk in FIG. 1), clustered separately from $D$. rampoddensis.

\section{Taxonomy}

Diploschistes rampoddensis (Nyl.) Zahlbr., Cat. Lich. Univers. 2: 665, 1924. Fig. 2A

Thallus saxicolous, crustose, yellowish grey to greenish yellow, without pruina but with a crystalliferous surface, $0.2-0.9 \mu \mathrm{m}$ thick, friable (easily broken), from verrucose-areolate to mostly reduced into conglutinated granules; epinecral layer 24-31 $\mu \mathrm{m}$ thick, without a well-developed cortex; photobiont trebouxioid.

AротнесіA urceolate, $0.2-1.3(-1.7) \mathrm{mm}$ in diam., never subdivided, with a deeply concave black disc with white pruina. ExcIPUlum black, 60-100 


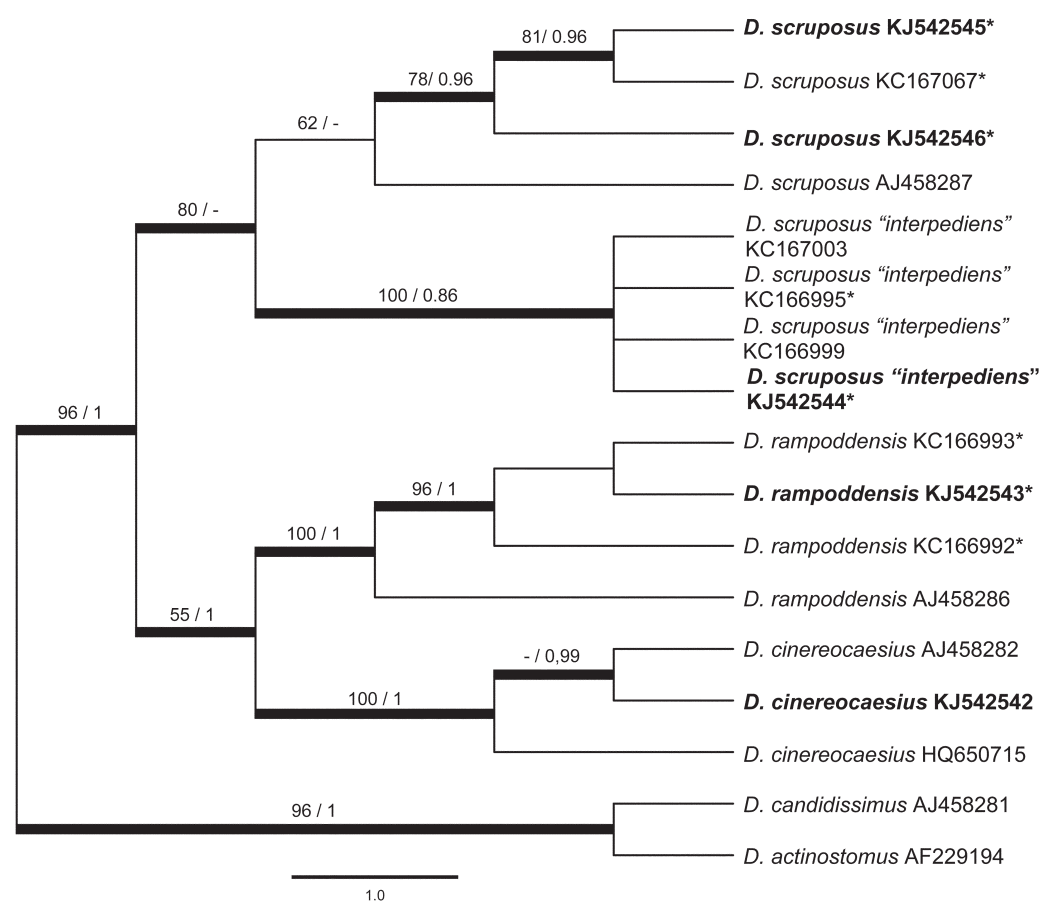

FIG. 1. Phylogenetic relationships of sequences of Diploschistes species summarized by a strict consensus tree of six equally most parsimonious trees, as revealed by the wMP analyses of the nrITS dataset, including 19 INAASE recoded characters. Bootstrap support $\geq 50 \%$ (BP; left) and posterior probabilities $\geq 0.5$ (PP; right) are shown above branches. Internodes with BP values $\geq 70 \%$ or PP $\geq 0.95$ are highlighted by thicker lines. Asterisk-marked specimens collected in the same locality of Sant Llorenç de la Muga (Catalonia, Spain). Newly generated sequences are presented in bold font.

$(-130) \mu \mathrm{m}$ thick, lateral paraphyses present. Нyмenium hyaline to pale brown, (78-)98-128(-134) $\mu \mathrm{m}$ high. Asci clavate, unitunicate, non-amyloid walls, (6-)8 spores per ascus, $100-170 \times 15-30 \mu \mathrm{m}$. Ascospores ellipsoid, pale to dark brown, non-amyloid, (19.5-)21- 26.5(-29) × (8.5-)9-12(-13.5) $\mu \mathrm{m}(\mathrm{n}=59)$, with 4-7(-8) transverse septa, and 1-2 longitudinal septa.

Chemistry - Spot test reactions of the thallus $\mathrm{K}-$ or $\mathrm{K}+$ pale yellow, $\mathrm{C}+$ and $\mathrm{KC}+$ pink (brief reaction). TLC: lecanoric acid as major compound, compounds in traces were not found.

Distribution \& HABitat - Since Diploschistes rampoddensis was first described by Nylander (1900) from material collected in Rampodde, Sri 

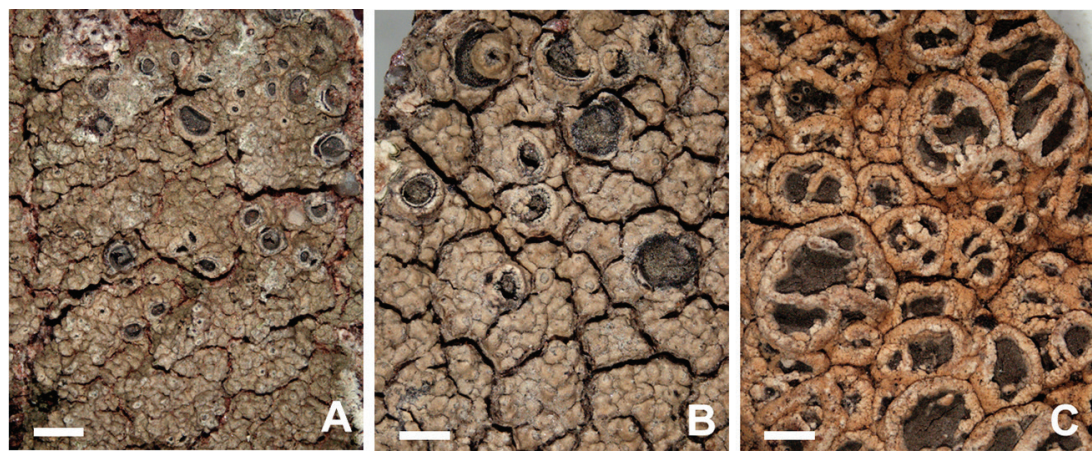

FIG. 2. A. Diploschistes rampoddensis (BCN-lich. 18011): habit. B. D. scruposus "interpediens" (BCN-lich. 14404): habit. C. D. cinereocaesius (BCN-lich. 18010): habit. Scale bars $=1 \mathrm{~mm}$.

Lanka, it has been recorded from a few Asian and Australasian localities: China (see examined specimens), India and Nepal (Pant \& Upreti 1993), Indonesia (Lumbsch 1993), and Papua New Guinea (Martín et al. 2003). The lichen usually occurs in lowlands and only rarely appears at high elevations of the intertropical region (Lumbsch 1993). Our study significantly extends its distribution to Europe, where it is reported only from a single locality, Sant Llorenç de la Muga (Catalonia, Spain). This area’s warm humid Mediterranean climate (with relatively high temperatures and humidity) has allowed the establishment of a rich foliicolous lichen flora (Llop \& Gómez-Bolea 2006), predominantly Atlantic bryophyte species such as Leucobryum juniperoideum (Brid.) C. Müll. (Brugués et al. 1974), and the pteridophyte Pellaea calomelanos (Sw.) Link earlier known from South Africa, northern India, and Macaronesia (Terradas \& Brugués 1973). The existence of these Atlantic and paleotropical elements in the study area would agree with the presence of Diploschistes rampoddensis outside its known pantropical distribution.

The European $D$. rampoddensis samples are saxicolous and grow on Garumnian red beds ( $\mathrm{HCl}-$ ). Pant \& Upreti (1993), however, reported the species colonizing sandstones from India.

Specimens examined - CHINA. Yunnan. Simao Distr. Mojiang Co., Mojiang (kmpost 350 from Kunming), along the main road, $23^{\circ} 26^{\prime} \mathrm{N} 101^{\circ} 41^{\prime} \mathrm{E}, 1200 \mathrm{~m}$, on hard soil, 12 Sep. 1987, Moberg \& Santesson 7702 (UPS L-11539); along the road E of the river Bavian Jiang ( $\mathrm{km}$-post 433 from Kunming), 23 $3^{\circ} 16^{\prime} \mathrm{N} 101^{\circ} 16^{\prime} \mathrm{E}, 1100 \mathrm{~m}$, on wayside rocks, 13 Sep. 1987, Moberg \& Santesson 31970 (UPS L-11540). SPAIN. Catalonia. Sant Llorenç de la Muga, path to Can Gener, UTM 31TDG8388, 150 m, Garumnian red beds, 9 Feb. 2007, Llimona \& Hladun (BCN-lich. 18011); cliffs by the river la Muga, near an old mine, UTM 31TDG8188, $280 \mathrm{~m}$, Garumnian red beds $45^{\circ}$ S-SW, 2 Mar. 2007, Llimona, Hladun \& Muñiz (BCN-lich. 18008, GenBank KJ542543; BCN-lich. 18009). 
Remarks -Diploschistes rampoddensis resembles octosporate specimens of D. scruposus (Fig. 2B; D. scruposus "morphotypus interpediens", hereafter abbreviated to D. scruposus "interpediens"), which also have (6-)8 ascospores per ascus and a similar ascospore size [(21-)23.5-27 × (9.5-)10-13(-13.5) $\mu \mathrm{m}]$. However, a detailed morphological comparison reveals that $D$. rampoddensis has a thinner and more delicate thallus than D. scruposus "interpediens." Their chemistry also differs: D. rampoddensis contains only lecanoric acid (major), while D. scruposus "interpediens" contains diploschistesic acid (minor) and orsellinic acid (minor), in addition to lecanoric acid (major) (Barbero 1998). Morphological and chemical differences between these two taxa are nonetheless really subtle, and the utilization of the nrITS was crucial in confirming the identity of the European specimens of D. rampoddensis.

Within Diploschistes, there are two other pantropically distributed species (D. cinereocaesius and D. hypoleucus Zahlbr.), which resemble D. rampoddensis in having a yellowish thallus, octosporous asci, and a rather similar ascospore size. These two species, however, are terricolous, have bigger apothecia that are usually secondarily subdivided (see D. cinereocaesius, FIG. 2C), and have different chemistry: D. cinereocaesius contains lecanoric acid (major) and diploschistesic acid (minor), while D. hypoleucus contains gyrophoric acid as a major compound. That Diploschistes rampoddensis and D. cinereocaesius appear as sister taxa in our phylogeny suggests a biogeographic pattern.

Additional specimens EXAMINED - Diploschistes cinereocaesius. COLOMBIA. Urrao. Páramo de Frontino, $6^{\circ} 25^{\prime} \mathrm{N} 76^{\circ} 05^{\prime} \mathrm{W}, 3500$ m, 30 June 1985, Churchill, SastreDe Jesús \& Escobar (DUKE 0144448). ECUADOR. ImbabURA. Laguna Cuicocha - NE edge, ca $9 \mathrm{~km}$ W of town Cotacachi, $00^{\circ} 18^{\prime} 43^{\prime \prime} \mathrm{N}, 78^{\circ} 21^{\prime} 15^{\prime \prime} \mathrm{W}$, on soil at trail-cutting, 3300-3350 m, 8 Oct. 2000, Palice 4471 \& Soldán (PRA, GenBank KJ542542) PERU. Huaraz. Route to Laguna Churup, $9^{\circ} 29^{\prime} \mathrm{S} 77^{\circ} 26^{\prime} \mathrm{W}, 4070 \mathrm{~m}, 25$ Aug. 2010, Rothfels 4000 \& Zylinski (BCN-lich. 18010).

Diploschistes scruposus. SPAIN. Catalonia. Girona, Sant Llorenç de la Muga, cliffs by the river la Muga, near an old mine, UTM 31TDG8188, $280 \mathrm{~m}$, Garumnian red beds $45^{\circ}$ S-SW, 2 Mar. 2007, Llimona, Hladun \& Muñiz (Hb. Fdez.-Brime, SFB 59, GenBank KJ542545; BCN-Lich 19326); cliffs by the river la Muga, UTM 31TDG8188, $240 \mathrm{~m}$, granitic outcrops $40^{\circ}$ S-SW, 3 June 2009, Fernández-Brime (Hb. Fdez.-Brime, SFB 103, GenBank KJ542546).

D. scruposus “interpediens". FRANCE. Pyrenées Orientales: Albera, road from Maurellans to Rinoguers, 31TDH85351, 300 m, granitic outcrops near the road, 13 June 2009, Llimona (BCN-Lich 19322). SPAIN. Catalonia. Barcelona, Òrrius, turó de Céllecs, 31T DG4400, 530 m, granitic outcrops, 23 Jan. 2009, Llimona \& FernándezBrime (BCN-Lich 19355). Girona, Sant Llorenç de la Muga, path to Can Gener, 31T DG8387, 140-150 m, Garumnian red beds, 9 Feb. 2007, Llimona \& Hladun (BCN-lich. 19319); cliffs by the river la Muga, UTM 31TDG8188, $260 \mathrm{~m}$, granitic outcrops $60^{\circ}$ E, 3 June 2009, Fernández-Brime (Hb. Fdez.-Brime, SFB 104, GenBank KJ542544). LA RiojA. Anguiano, electric power station, 30T WM1878, $670 \mathrm{~m}$, Quercus ilex forest, 8 Sep. 2004, Hladun \& Muñiz (BCN-Lich 14404). 


\section{Acknowledgments}

The authors thank the herbaria of BCN, DUKE, PRA, UPS and Dr. Diana Muñiz and Dr. Carl Rothfels for providing material used in the present study, Dr. Thorsten Lumbsch for generating sequences used in this study, Dr. Ana Rosa Burgaz and Dr Yogesh Joshi for presubmission review, Molly McMullen and Dr. Robert Lachlan for the English revision, and Dr. Shaun Pennycook for the nomenclature review. This work was supported by the projects 'Filogènia molecular de les Teloschistales i Ostropales. Part II' and 'Biodiversitat dels Fongs i Líquens dels Països Catalans' (PIN2012-S02) both funded by the Institut d'Estudis Catalans, with the contribution of the 'Fons Memorial Salvador Llimona'

\section{Literature cited}

Barbero MM. 1998. Estudio florístico y quimiotaxonómico de los líquenes silicícolas del Maresme. Ph.D. thesis, University of Barcelona.

Brugués M, Casas de Puig C, Cros RM. 1974. Aportación a la brioflora catalana. Leucobryum juniperoideum (Brid.) C Müll en los alcornocales del Alto Ampurdán. Anales Inst. Bot. Cavanilles 31: 109-117.

Felsenstein J. 1985. Confidence limits on phylogenies: an approach using the bootstrap. Evolution 39: 783-791. http://dx.doi.org/10.2307/2408678

Fernández-Brime S, Llimona X, Lutzoni F, Gaya E. 2013. Phylogenetic study of Diploschistes (Graphidaceae, Ostropales, lichen-forming Ascomycota), based on morphological, chemical, and molecular data. Taxon 62: 267-280. http://dx.doi.org/10.12705/622.10

Gardes M, Bruns TD. 1993. ITS primers with enhanced specificity for basidiomycetes: application to the identification of mycorrhizae and rusts. Mol. Ecol. 2: 113-118. http://dx.doi.org/10.1111/j.1365-294X.1993.tb00005.x

Gaya E, Lutzoni F, Zoller S, Navarro-Rosinés P. 2003. Phylogenetic study of Fulgensia and allied Caloplaca and Xanthoria species (Teloschistaceae, lichen-forming Ascomycota). Amer. J. Bot. 90: 1095-1103. http://dx.doi.org/10.3732/ajb.90.7.1095

Gaya E, Navarro-Rosinés P, Llimona X, Hladun N, Lutzoni F. 2008. Phylogenetic reassessment of the Teloschistaceae (lichen forming Ascomycota, Lecanoromycetes). Mycol. Res. 112: 528-546. http://dx.doi.org/10.1016/j.mycres.2007.11.005

Gaya E, Redelings BD, Navarro-Rosinés P, Llimona X, de Cáceres M, Lutzoni F. 2011. Align or not to align? Resolving species complexes within the Caloplaca saxicola group as a case study. Mycologia 103: 361-378. http://dx.doi.org/10.3852/10-120

Gueidan C, Roux C, Lutzoni F. 2007. Using a multigene phylogenetic analysis to assess generic delineation and character evolution in Verrucariaceae (Eurotiomycetes, Ascomycota). Mycol. Res. 111: 1145-1168. http://dx.doi.org/10.1016/j.mycres.2007.08.010

Kirk PM, Cannon PF, Minter DW, Stalpers JA. 2008. Ainsworth \& Bisby's dictionary of the fungi. 10th edition. CAB International, Wallingford.

Lee SB, Milgroom MG, Taylor JW. 1988. A rapid, high yield mini-prep method for isolation of total genomic DNA from fungi. Fungal Genet. Newslett. 35: 23-24.

Llop E, Gómez-Bolea A. 2006 Foliicolous lichens and associated lichenicolous fungi in the northeastern Iberian Peninsula: the effect of environmental factors on distribution. Lichenologist 38: 55-65. http://dx.doi.org/10.1017/S0024282905014362

Lumbsch HT. 1989. Die holarktischen Vertreter der Flechtengattung Diploschistes (Thelotremataceae). J. Hattori Bot. Lab. 66: 133-196.

Lumbsch HT. 1993. Studien über die Flechtengattung Diploschistes I. Nova Hedwigia 56: 227-236. 
Lutzoni F, Wagner P, Reeb V, Zoller S. 2000. Integrating ambiguously aligned regions of DNA sequences in phylogenetic analyses without violating positional homology. Syst. Biol. 49: 628-651. http://dx.doi.org/10.1080/106351500750049743

Maddison WP, Maddison DR. 2011. Mesquite: a modular system for evolutionary analysis. Version 2.75. http://mesquiteproject.org.

Martín MP, Winka K. 2000: Alternative methods of extracting and amplifying DNA from lichens. Lichenologist 32: 189-196.

Martín MP, LaGreca S, Lumbsch HT. 2003. Molecular phylogeny of Diploschistes inferred from ITS sequence data. Lichenologist 35: 27-32.

Nylander W. 1900. Lichenes ceylonenses et additamentum ad lichenes japoniae. Acta Soc. Sci. Fenn. 26: 1-33.

Orange A, James PW, White, FJ. 2001. Microchemical methods for the identification of lichens. British Lichen Society, London.

Pant G, Upreti DK. 1993. The lichen genus Diploschistes in India and Nepal. Lichenologist 25: 33-50. http://dx.doi.org/10.1017/S0024282993000040

Pérez-Vargas I, Hernández-Padrón C, Pérez De Paz PL, Elix JA. 2012. A new saxicolous species of Diploschistes (Thelotremataceae) from the Canary Islands. Lichenologist 44: 67-71. http://dx.doi.org/10.1017/S0024282911000612

Redelings BD, Suchard MA. 2007. Incorporating indel information into phylogeny estimation for rapidly emerging pathogens. BMC Evol. Biol. 7: 40. http://dx.doi.org/10.1186/1471-2148-7-40

Schoch CL et al. 2012. Nuclear ribosomal internal transcribed spacer(ITS) region as a universal DNA barcode marker for fungi. PNAS 109: 6241-6246. http://dx.doi.org/10.1073/pnas.1117018109

Suchard M, Redelings BD. 2006. BAli-Phy: simultaneous Bayesian inference of alignment and phylogeny. Bioinformatics 22: 2047-2048. http://dx.doi.org/10.1093/bioinformatics/btl175

Swofford DL. 2002. PAUP*: Phylogenetic analysis using parsimony ${ }^{*}$ and other methods), version 4.0b10. Sunderland, Massachusetts: Sinauer.

Terradas JA, Brugués M. 1973. Una nueva localidad de Pellaea calomelanos en Cataluña. Acta Geobot. Barcinon. 8: 1-15.

White TJ, Bruns T, Lee S, Taylor JW. 1990. Amplification and direct sequencing of fungal ribosomal RNA genes for phylogenetics. 315-322 in: MA Innis et al. (eds). PCR protocols: a guide to methods and applications. Academic Press, San Diego. 